\title{
Left ventricular haemodynamics before and soon after saphenous vein bypass graft operation for angina pectoris
}

\author{
Barry D. Rutherford, Gerald T. Gau, Gordon K. Danielson, James R. Pluth, \\ George D. Davis, Robert B. Wallace, and Robert L. Frye \\ From the Mayo Clinic and Mayo Foundation, Rochester, Minnesota, U.S.A.
}

Twenty-six patients with coronary artery disease undergoing saphenous vein bypass grafts for treatment of angina pectoris were studied with preoperative and early postoperative left ventricular haemodynamics at rest and during mild supine leg exercise. In approximately 70 per cent of the $2 I$ patients with a patent graft, a return toward normal left ventricular function during exercise was noted on the basis of the absolute level of left ventricular end-diastolic pressure during exercise, and the relation between change in left ventricular end-diastolic pressure and left ventricular stroke work index during exercise. Though the explanation for lack of haemodynamic improvement in patients with a patent graft is not always clear, inadequate revascularization in terms of the number of vessels involved may be an important factor, in addition to the actual amount of flow in the graft and the preoperative state of the ventricle.

In 1954, experimental studies in dogs by Murray et al. demonstrated a technique of anastomosis of a vein graft between the ascending aorta and the distal segment of a coronary artery with a ligature about the proximal vessel. They suggested this procedure as a possible surgical approach to the treatment of patients with coronary artery disease. The first description of the clinical application of the saphenous vein bypass operation in patients with coronary artery disease was in 1969 by Favaloro and by Johnson et al. The present study was designed to evaluate the effect of aorto-coronary arterysaphenous vein grafts on left ventricular function at rest and during exercise in patients with coronary artery disease undergoing this procedure for treatment of angina pectoris.

\section{Methods}

Approximately 200 patients with coronary artery disease underwent saphenous vein bypass graft procedures at the Mayo Clinic between 1968 and 1970. Preoperative and postoperative studies were made of left ventricular haemodynamics of 26 of these patients at rest and during supine leg exercise as well as angiographic evaluation of the vein graft (or grafts) within 7 months after operation.

The patients were selected only on the basis of

Received 13 April 1972. having had adequate preoperative exercise studies and of giving their consent for postoperative visualization of the grafts. Patients, however, were given the opportunity to refuse the study after full explanation of the risks and objectives of the procedure. Attempts were made to visualize as many grafts as possible.

This study was carried out early in the total experience of this operation and the surgical staff thought it necessary to visualize as many grafts as possible soon after operation for accurate assessment of the results.

The 26 patients, 24 of whom were men, ranged in age from 35 to 67 years (mean age, 50 years). Because of angina pectoris, all patients were significantly disabled and considered surgical candidates for relief of pain. The postoperative studies were performed 8 days to 7 months (mean period, 38 days) after surgical treatment.

None of the patients had valvular disease, cardiomegaly, or other clinical evidence of congestive heart failure. The patients were fasting and premedicated with $100 \mathrm{mg}$ pentobarbitone sodium given intramuscularly; none had received any nitrates within 8 hours of the study. No medication known to influence left ventricular function was being administered and all patients were ambulatory. All haemodynamic studies were performed at the time of coronary arteriography but before the injection of contrast material.

The methods employed for the haemodynamic studies were identical for each patient during the the studies (before and after operation) and have been reported previously (McCallister et al., I968, 


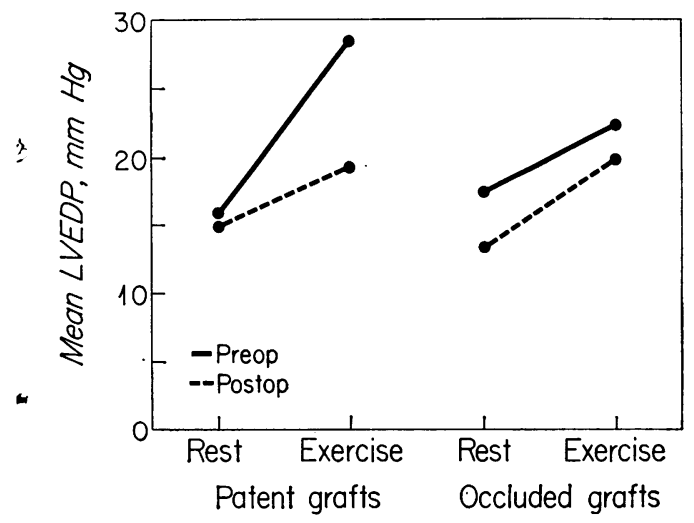

FIG. I Mean left ventricular end-diastolic pressure (LVEDP) at rest and during exercise, before and after operation, in patients with

- patent and occluded vein grafts.

1970). Left ventricular and systemic arterial pressures, cardiac output, and heart rate were measured with the patient at rest supine, with the feet raised for 5 minutes on the bicycle ergometer, - and after 3 minutes of supine leg exercise at a load of $150 \mathrm{~kg} \mathrm{~m}$. The cardiac output during exercise was not measured in 4 patients who had angina because they could not continue the exercise for 3 minutes. In 5 other patients, cardiac output could not be measured because of problems with arterial sampling.

Coronary arteriography and selective injection

4 of meglumine diatrizoate into the vein graft or grafts were performed by the Sones technique. Grading of the extent of coronary disease is that described by Saltups et al. (1971). Significant obstructive lesions were based on an estimate of at least a 50 per cent reduction in diameter of the involved vessel. A significant obstruction in the proximal left anterior descending or the left circumflex coronary artery was graded 2 , while a lesion distal to the origin of a diagonal or marginal

r branch was graded I. A significant obstructive lesion in the right coronary artery was graded $\mathbf{I}$, while if the left main coronary was involved, the lesion was graded 4.

Eight patients had a graft to the right coronary artery alone, 9 to the left anterior descending alone, 7 to the right coronary and left anterior descending arteries, one to the left anterior de-

- scending and circumflex arteries, and one to the left anterior descending, circumflex, and right coronary arteries.

-

\section{Results}

The patients have been divided into two y. groups depending on the state of the vein graft at the time of postoperative study. In 2I patients (group I) one or more vein grafts were patent, while in 5 (group 2) all grafts
TABLE I Clinical and angiographic data

\begin{tabular}{|c|c|c|c|c|c|c|}
\hline \multirow{2}{*}{$\begin{array}{l}\text { Case } \\
\text { No. }\end{array}$} & \multirow{2}{*}{$\begin{array}{l}\text { Extent of } \\
\text { coronary } \\
\text { artery } \\
\text { defect }\end{array}$} & \multirow[t]{2}{*}{ Collaterals } & \multicolumn{2}{|c|}{ Myocardial infarction } & \multirow[t]{2}{*}{ Vein grafts } & \multirow{2}{*}{$\begin{array}{l}\text { Interval } \\
\text { between } \\
\text { operation } \\
\text { and study }\end{array}$} \\
\hline & & & $\begin{array}{l}\text { Before } \\
\text { operation }\end{array}$ & $\begin{array}{l}\text { After } \\
\text { operation }\end{array}$ & & \\
\hline \multicolumn{7}{|c|}{ Group I } \\
\hline $\mathbf{I}$ & 5 & - & + & - & $\mathbf{R}$ & IO dy \\
\hline 2 & 3 & + & - & - & $\mathbf{R}$ & Io dy \\
\hline 3 & 3 & + & + & - & $\mathbf{R}$ & $9 \mathrm{dy}$ \\
\hline 4 & I & + & - & - & $\mathbf{R}$ & $14 \mathrm{dy}$ \\
\hline 5 & 3 & + & + & - & LAD & $8 \mathrm{dy}$ \\
\hline 6 & 2 & + & - & - & LAD & I0 dy \\
\hline 7 & 2 & - & - & - & LAD & $14 d y$ \\
\hline 8 & 2 & + & + & - & LAD & $9 \mathrm{dy}$ \\
\hline 9 & 4 & + & - & - & $R$ and LAD & IO dy \\
\hline 10 & 3 & + & - & - & $\mathbf{R}$ and $\mathrm{LAD} \dagger$ & 4 wk \\
\hline II & 3 & - & + & - & $R$ and LAD & $13 d y$ \\
\hline 12 & 4 & + & + & - & $\mathbf{R}$ and LAD† & $13 \mathrm{dy}$ \\
\hline 13 & 3 & - & - & - & LAD & Io wk \\
\hline 14 & 2 & + & - & - & LAD & $5 \mathrm{wk}$ \\
\hline 15 & 5 & + & - & - & $\mathbf{R}$ and LAD & 9 dy \\
\hline 16 & 5 & + & - & - & $\mathbf{R}$ and $\mathbf{L A D}$ & $12 \mathrm{dy}$ \\
\hline 17 & 5 & + & - & - & LAD & $9 \mathrm{dy}$ \\
\hline 18 & 4 & + & - & - & LAD and LC & $4 \mathrm{wk}$ \\
\hline 19 & 4 & + & + & - & $R$ and $L A D$ & $12 \mathrm{dy}$ \\
\hline 20 & 5 & - & - & - & $\mathbf{R}, \mathbf{L A D}, \ddagger \mathrm{LC} \ddagger$ & 4 wk \\
\hline $2 I$ & 3 & - & + & - & $\mathbf{R}$ & 5 wk \\
\hline \multicolumn{7}{|c|}{ Group 2} \\
\hline 22 & 2 & - & - & + & LAD† & II dy \\
\hline 23 & 2 & + & + & - & $\mathrm{Rt}$ & $6 \mathrm{wk}$ \\
\hline 24 & $\mathbf{I}$ & + & - & - & $\mathbf{R +}$ & $7 \mathrm{mth}$ \\
\hline 25 & 3 & - & - & + & R† & $7 \mathrm{mth}$ \\
\hline 26 & 2 & - & - & + & LAD† & $4 \mathrm{mth}$ \\
\hline
\end{tabular}

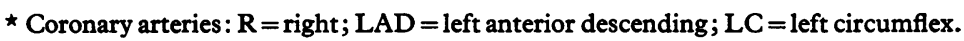
† Occluded graft.

$\ddagger$ Nonselective injection of graft.

FIG. 2 Comparison of preoperative and postoperative rest and exercise on left ventricular end-diastolic pressure.

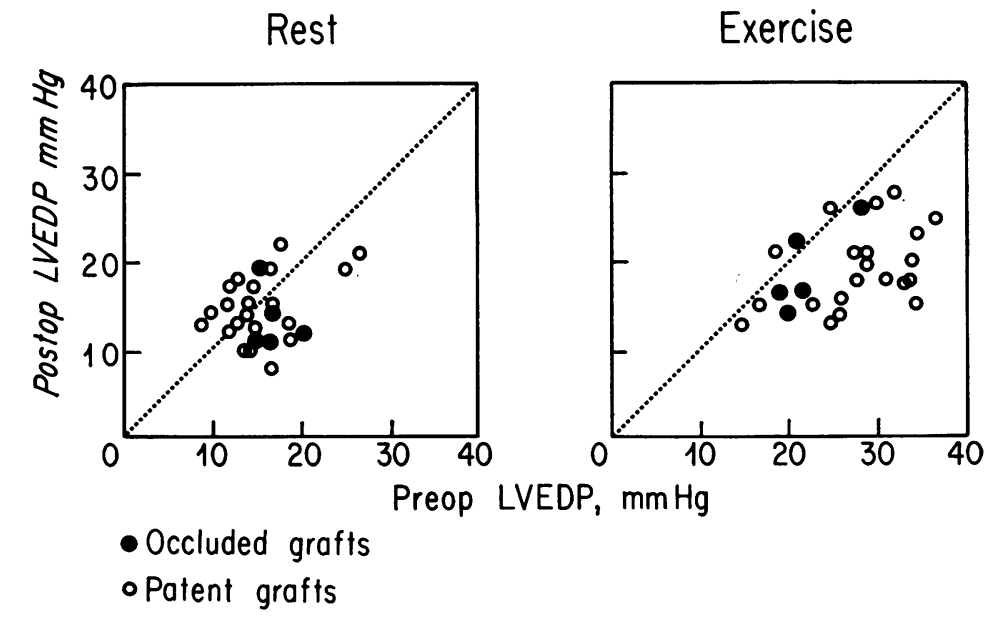


were occluded. All 5 patients in group 2 had single grafts.

Table I contains clinical and arteriographic data. Tables 2 and 3 list the haemodynamic data for each patient.

Preoperative and postoperative measurements of stroke volume index, mean arterial pressure, and heart rate were comparable in the two groups. In both groups, mean arterial pressure was lower and heart rate was higher at rest and during exercise at the time of postoperative study. Unfortunately there was a difference in the preoperative characteristics of the two groups in relation to changes in left ventricular end-diastolic pressure during exercise. Patients who had patent grafts after operation showed a conspicuous increase in left ventricular end-diastolic pressure with exercise when tested before operation. The effect of operation on the response to exercise was striking in that after operation the patients with patent grafts showed a relatively small increase in left ventricular end-diastolic pressure with exercise (Fig. I). The group of

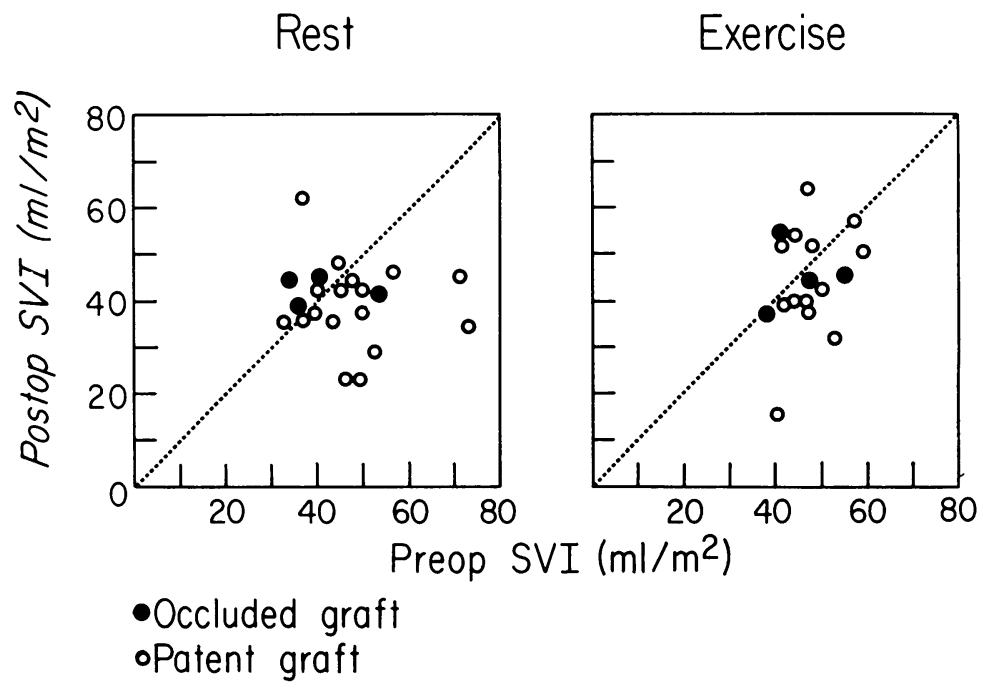

FIG. 3 Comparison of preoperative and postoperative resting and exercise stroke volume index.

TABLE 2 Left ventricular end-diastolic pressure and stroke volume index

\begin{tabular}{|c|c|c|c|c|c|c|c|c|}
\hline \multirow{3}{*}{$\begin{array}{l}\text { Case } \\
\text { No. }\end{array}$} & \multicolumn{4}{|c|}{ Left ventricular end-diastolic pressure $(\mathrm{mmHg})$} & \multicolumn{4}{|c|}{ Stroke volume index $\left(\mathrm{ml} / \mathrm{m}^{2}\right)$} \\
\hline & \multicolumn{2}{|l|}{ Rest } & \multicolumn{2}{|l|}{ Exercise } & \multicolumn{2}{|l|}{ Rest } & \multicolumn{2}{|l|}{ Exercise } \\
\hline & $\begin{array}{l}\text { Before } \\
\text { operation }\end{array}$ & $\begin{array}{l}\text { After } \\
\text { operation }\end{array}$ & $\begin{array}{l}\text { Before } \\
\text { operation }\end{array}$ & $\begin{array}{l}\text { After } \\
\text { operation }\end{array}$ & $\begin{array}{l}\text { Before } \\
\text { operation }\end{array}$ & $\begin{array}{l}\text { After } \\
\text { operation }\end{array}$ & $\begin{array}{l}\text { Before } \\
\text { operation }\end{array}$ & $\begin{array}{l}\text { After } \\
\text { operation }\end{array}$ \\
\hline \multicolumn{9}{|c|}{ Group I } \\
\hline I & I4 & 22 & 25 & 26 & 37 & 62 & 47 & 64 \\
\hline 2 & 27 & $2 I$ & 37 & 25 & 45 & 42 & 48 & $5 \mathrm{I}$ \\
\hline 3 & 14 & Io & 26 & I4 & 45 & 48 & 59 & 50 \\
\hline 4 & 19 & 13 & 26 & 15 & $4 I$ & 42 & $4 I$ & 52 \\
\hline 5 & 14 & 15 & 23 & I5 & $7 I$ & 45 & 50 & 42 \\
\hline 6 & 12 & 12 & 17 & 15 & 45 & - & 44 & - \\
\hline 7 & 15 & 12 & 25 & 13 & 56 & - & 60 & - \\
\hline 8 & 19 & II & 31 & 18 & 50 & 37 & $5 I$ & - \\
\hline 9 & 12 & 15 & 29 & $2 \mathrm{I}$ & 49 & 23 & - & 27 \\
\hline IO & 12 & 17 & 28 & $2 I$ & 33 & 35 & - & 44 \\
\hline II & I5 & 17 & 29 & 20 & 50 & - & 47 & - \\
\hline 12 & 9 & I3 & I5 & 13 & 53 & 29 & 42 & 39 \\
\hline 13 & I6 & 19 & 32 & 28 & 50 & 42 & 44 & 53 \\
\hline 14 & I7 & I5 & 34 & 13 & 48 & 44 & 47 & 38 \\
\hline 15 & 13 & $\mathrm{I} 8$ & 30 & 27 & 46 & 23 & 40 & 15 \\
\hline 16 & I4 & I4 & 28 & 18 & 37 & 36 & 46 & 39 \\
\hline 17 & 26 & 14 & 39 & 22 & 73 & 34 & 53 & 31 \\
\hline 18 & 10 & I4 & 19 & 2I & 57 & 46 & 57 & 57 \\
\hline 19 & 13 & 13 & 33 & 18 & 44 & 35 & - & 36 \\
\hline 20 & 14 & Io & 34 & 15 & - & 28 & - & 36 \\
\hline 21 & 25 & 19 & 34 & 22 & 39 & 37 & 43 & 39 \\
\hline Mean & 16 & 15 & 28 & 19 & 48 & 38 & 48 & 42 \\
\hline \multicolumn{9}{|c|}{ Group 2} \\
\hline 22 & 20 & I I & 20 & 17 & - & 31 & 一 & 25 \\
\hline 23 & 17 & I4 & $2 I$ & 22 & $4 I$ & 45 & 55 & 45 \\
\hline 24 & 17 & II & 22 & 17 & 34 & 44 & 4I & 53 \\
\hline 25 & I5 & I I & 19 & I6 & 36 & 38 & 38 & 37 \\
\hline 26 & I8 & 19 & 29 & 27 & 54 & $4 I$ & 47 & 44 \\
\hline Mean & 17 & 13 & 22 & 19 & $4 I$ & 40 & 45 & $4 I$ \\
\hline
\end{tabular}


TABLE 3 Mean arterial pressure and heart rate

\begin{tabular}{|c|c|c|c|c|c|c|c|c|}
\hline \multirow{3}{*}{$\begin{array}{l}\text { Case } \\
\text { No. }\end{array}$} & \multicolumn{4}{|c|}{ Mean arterial pressure $(\mathrm{mmHg})$} & \multicolumn{4}{|c|}{ Heart rate (beats /min) } \\
\hline & \multicolumn{2}{|l|}{ Rest } & \multicolumn{2}{|l|}{ Exercise } & \multicolumn{2}{|l|}{ Rest } & \multicolumn{2}{|l|}{ Exercise } \\
\hline & $\begin{array}{l}\text { Before } \\
\text { operation }\end{array}$ & $\begin{array}{l}\text { After } \\
\text { operation }\end{array}$ & $\begin{array}{l}\text { Before } \\
\text { operation }\end{array}$ & $\begin{array}{l}\text { After } \\
\text { operation }\end{array}$ & $\begin{array}{l}\text { Before } \\
\text { operation }\end{array}$ & $\begin{array}{l}\text { After } \\
\text { operation }\end{array}$ & $\begin{array}{l}\text { Before } \\
\text { operation }\end{array}$ & $\begin{array}{l}\text { After } \\
\text { operation }\end{array}$ \\
\hline \multicolumn{9}{|c|}{ Group I } \\
\hline $\mathbf{I}$ & III & IOI & 113 & II6 & 76 & 60 & 88 & 70 \\
\hline 2 & 108 & 100 & 109 & IIO & 70 & 80 & 80 & 80 \\
\hline 3 & 90 & 71 & 109 & 84 & 60 & 80 & 79 & 90 \\
\hline 4 & 97 & 63 & 108 & 85 & 54 & 60 & 72 & 80 \\
\hline 5 & 102 & 102 & II7 & 107 & 70 & 85 & 80 & 95 \\
\hline 6 & $118^{\star}$ & $102 \star$ & $140^{\star}$ & $125^{\star}$ & 60 & 100 & 78 & IIO \\
\hline 7 & $107^{\star}$ & $107^{\star}$ & $145^{\star}$ & $127^{\star}$ & 50 & 76 & 80 & 84 \\
\hline 8 & $115^{\star}$ & $118^{\star}$ & $130^{\star}$ & $136^{\star}$ & 78 & 80 & 84 & 90 \\
\hline 9 & $13^{\star}$ & $108^{\star}$ & $133^{\star}$ & $130^{\star}$ & 85 & 90 & 85 & 100 \\
\hline I0 & $142^{\star}$ & $160^{\star}$ & $190^{\star}$ & $200 \star$ & 60 & 64 & 90 & 96 \\
\hline II & IOI $^{\star}$ & IOI $^{\star}$ & $122^{\star}$ & I I $4^{\star}$ & 60 & 90 & 70 & 100 \\
\hline 12 & 96 & 93 & 103 & IOI & 78 & 92 & 90 & 100 \\
\hline 13 & 99 & 105 & II 8 & II 7 & 69 & 60 & 93 & 90 \\
\hline 14 & 95 & IOI & 98 & II2 & 63 & 75 & 92 & 93 \\
\hline 15 & 113 & 102 & II 8 & II3 & 90 & 90 & II4 & 122 \\
\hline 16 & 132 & 96 & I43 & 109 & 78 & 84 & 90 & 96 \\
\hline 17 & IIO & 81 & 123 & 97 & 48 & 104 & 90 & 120 \\
\hline 18 & 102 & III & II9 & II & 56 & 76 & 76 & 90 \\
\hline 19 & 110 & 94 & III & 117 & 72 & 90 & 90 & 102 \\
\hline 20 & 106 & 87 & 120 & 106 & 54 & 72 & 96 & 96 \\
\hline 21 & 108 & 89 & 119 & 97 & 66 & 68 & 90 & 84 \\
\hline Mean & 105 & 93 & II 5 & 106 & 67 & 80 & 86 & 95 \\
\hline \multicolumn{9}{|c|}{ Group 2} \\
\hline 22 & $175^{\star}$ & $120^{\star}$ & $178^{\star}$ & $150^{\star}$ & 72 & 84 & 85 & 102 \\
\hline 23 & IOI & 88 & I IO & 100 & 66 & 65 & 73 & 75 \\
\hline 24 & 100 & 94 & I I I & 107 & 56 & 55 & 74 & 80 \\
\hline 25 & 99 & 95 & 113 & IOI & 58 & 65 & 72 & 90 \\
\hline 26 & 95 & 100 & II7 & 109 & 54 & 78 & 80 & 96 \\
\hline Mean & 99 & 94 & II3 & 104 & $6 I$ & 69 & 77 & 89 \\
\hline
\end{tabular}

* Peak left ventricular systolic pressure (not included in mean values).

patients with occluded grafts had only small

- increases in left ventricular end-diastolic pressure during exercise before operation and similar increases when tested after operation. Thus, our results show a positive effect of successful operations when comparing groups of patients with patent and occluded grafts with relation to increases in left ventricular

- end-diastolic pressure during exercise $(\mathrm{P}<0 \cdot 00 \mathrm{I})$.

Of more importance than the group means is an analysis of individual patients using each patient as his own control. Considerable individual variation in haemodynamics existed in measurements before and after operation (Fig.

- 2, 3, 4, and 5). It is noted that there are exceptions to the generalization that patients with patent grafts showed lower levels of left ventricular end-diastolic pressure during exercise when compared with values before operation.

In I5 patients with patent grafts, left ventricular end-diastolic pressures were at least $8 \mathrm{mmHg}$ lower during exercise after opera-
FIG. 4 Comparison of preoperative and postoperative resting and exercise heart rate.

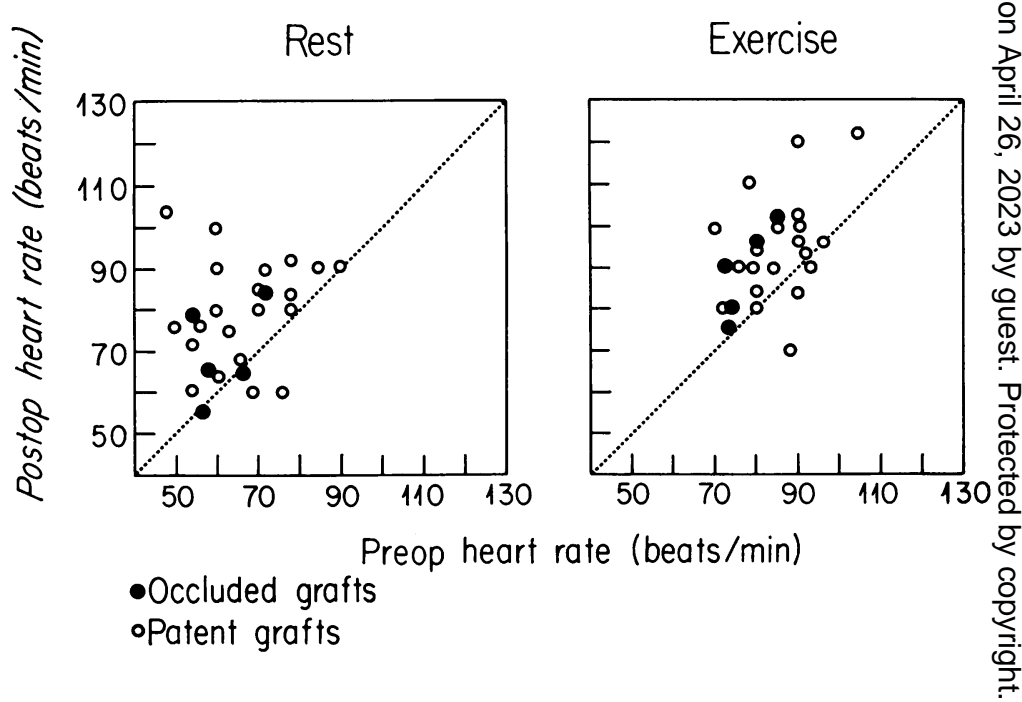


tion than before operation. None of the patients with occluded grafts had a similar pattern of response. Of the remaining 6 patients in group I, 3 patients (Cases 10, 13, and 15) had significant involvement of other coronary arteries not adequately revascularized and in 3 patients the left ventricular end-diastolic pressure during exercise before operation was $20 \mathrm{mmHg}$ or less, indicating less severe impairment of left ventricular function and thus less likelihood of showing improvement.

Fig. 6 shows the relation between the change in left ventricular end-diastolic pressure and left ventricular stroke work index during exercise before and after operation. All 26 patients are not included since some did not have cardiac output measurement for the reasons stated previously. Most of the patients with a patent graft showed improvement in left ventricular function. All patients with an open graft had an increase in left ventricular end-diastolic pressure with exercise greater than $5 \mathrm{mmHg}$ before operation. Nine of these patients exercised in an identical manner after operation had an increase in left ventricular end-diastolic pressure of $4 \mathrm{mmHg}$ or less with similar or greater increases in left ventricular stroke work index compared to the preoperative study. Three of 4 patients (Cases 15,17 , and 18 ) with increases in left ventricular end-diastolic pressure of more than $4 \mathrm{mmHg}$ during exercise postoperatively had coronary arteries with significant obstruction and no vein graft established to these vessels. A similar pattern of improved left ventricular function was not observed in the 4 patients with occluded grafts.

\section{Discussion}

The problems of assessing results of surgical treatment for angina pectoris in patients with coronary artery disease have been emphasized previously (Dimond, Kittle, and Crockett, 1960). However, in terms of the objective for which the operation is performed, that is, relief of pain, reports regarding results of saphenous vein bypass graft surgery are favourable (Favaloro et al., 1970; Johnson and Lepley, 1970). In spite of this, it does seem important to continue attempts to evaluate objectively the results of such operations. In the early postoperative period, the present study showed a return toward normal of left ventricular function during mild supine leg exercise in approximately 70 per cent of the patients who underwent adequate revascularization by the saphenous vein graft technique. It is significant that this conclusion cannot

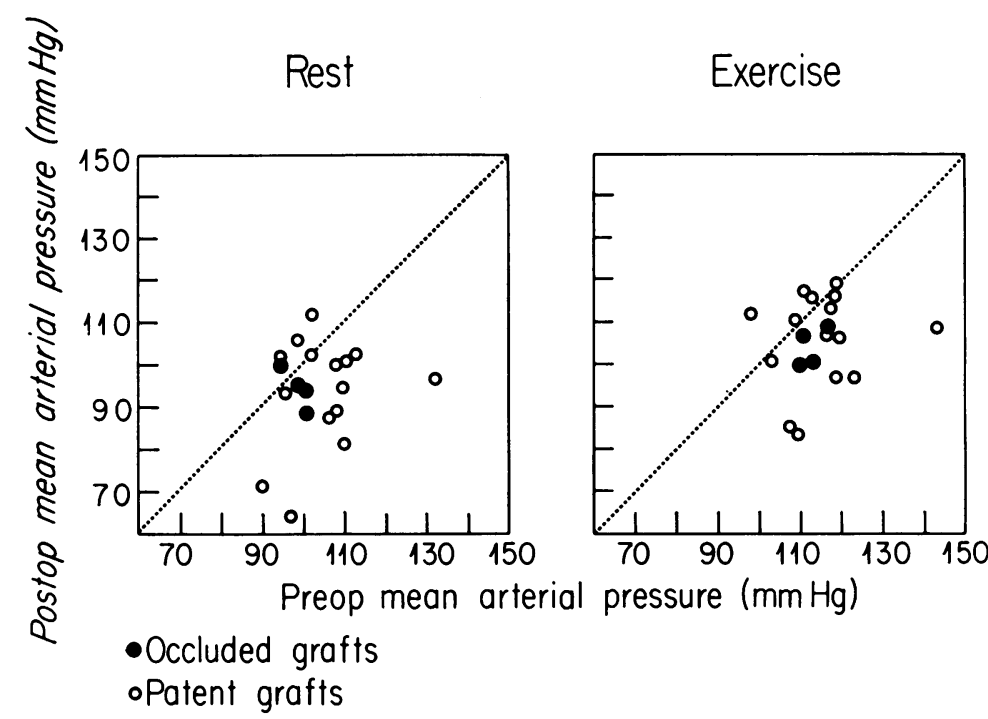

FIG. 5 Comparison of preoperative and postoperative resting and exercise mean arterial pressure.

be reached from evaluation of the resting haemodynamics alone.

It is difficult to prove at this time that the change in left ventricular haemodynamics during exercise after operation is due to relief of myocardial ischaemia by the flow provided through the vein graft. The application of roentgen videodensitometry to the measurement of flow in the vein grafts should provide

FIG. 6 Relation between change in left ventricular end-diastolic pressure and stroke work index before and after operation in patients with patent and occluded grafts.
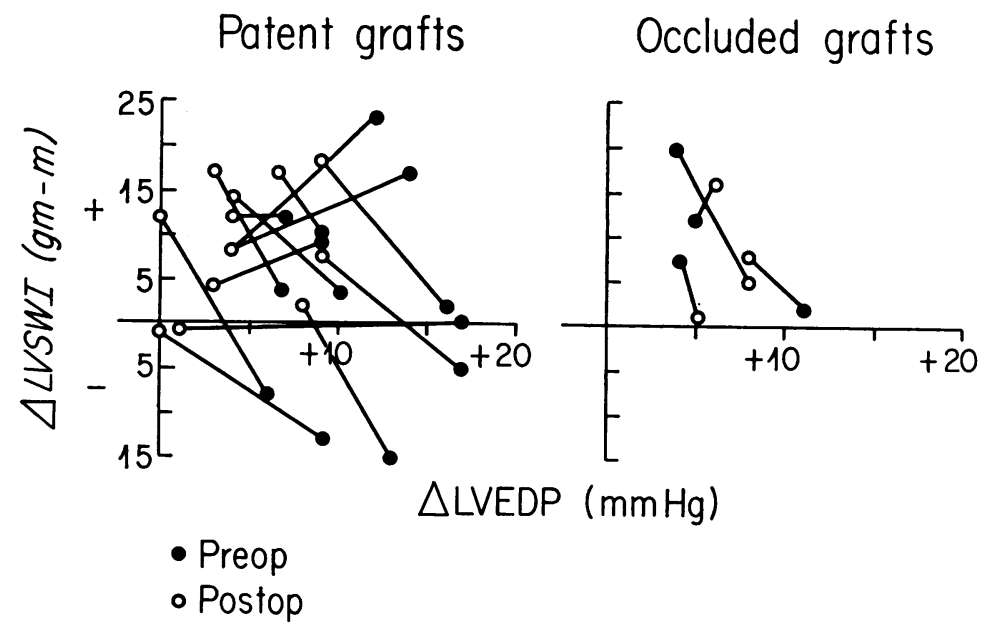
a more precise method of evaluating response to surgery (Smith et al., I97I). Thus, though patients may have patent grafts, the flow may be somewhat low. This phenomenon may explain why the haemodynamics in some of the patients in group I did not improve. Ample experimental data in animals, however, show abnormal left ventricular function with myocardial ischaemia and the reversible nature of such changes when the ischaemia is relieved (Sarnoff, I955; Tatooles and Randall, 196I; Tennant and Wiggers, 1935). It is recognized that many factors may influence the left ventricular end-diastolic pressure. Consideration must be given to the possibility that the apparently improved performance of the left ventricle after operation in the present study is a nonspecific one related to the post-

- operative period of rest in bed, a different haemodynamic state, or other unknown factors. This result seems unlikely in view of the absence of similar changes in patients with occluded grafts. Study of more patients with occluded grafts could obviously strengthen this point. Eleven of the 15 patients with left

- ventricular end-diastolic pressure during exercise of at least $8 \mathrm{mmHg}$ less than preoperative values had mean arterial or peak left ventricular systolic pressures within I6 $\mathrm{mmHg}$ on comparison of values during exercise before and after operation. Thus, it seems unlikely that the lower left ventricular - end-diastolic pressure during exercise is due solely to a reduced afterload at the time of postoperative study. Further study of these patients, a year or more after operation, is planned, however, to help in assessment of this early observation.

Quantitative data on the analysis of left ventriculograms in the present group of patients are not available. However, surgeons - (Favaloro et al., 1970; Johnson and Lepley, 1970) have described changes in the appearance of ventricular contraction at the time of operation subsequent to successful vein bypass grafts, and recently several groups (Campeau et al., 1970; Rees et al., 1970) have reported improvement in quantitative indexes A of left ventricular function determined by analysis of left ventriculograms.

The relation between these observed haemodynamic changes and the future clinical state of the patient is not clear. Additional studies with careful clinical follow-up at yearly intervals after these surgical procedures are planned to help clarify this point. Similar haemodynamic studies of patients a year after implantation of an internal mammary artery for relief of angina pectoris have been reported. In the majority of these patients, haemodynamic evidence for improved left ventricular function was lacking (McCallister et al., 1970).

The authors wish to express appreciation to Dr. William F. Taylor and Mr. Duane M. Ilstrup for advice and statistical analysis of the data presented.

\section{References}

Campeau, L., Eibar, J., Lespérance, J., Saltiel, J., and Castonguay, Y. (1970). Myocardial function following aorto-coronary vein graft surgery (abstract). Circulation, 41, Suppl. 3, 107.

Dimond, E. G., Kittle, C. F., and Crockett, J. E. (1960). Comparison of internal mammary artery ligation and sham operation for angina pectoris. American Fournal of Cardiology, 5, 483.

Favaloro, R. G. (1969). Saphenous vein graft in the surgical treatment of coronary artery disease: operative technique. Fournal of Thoracic and Cardiovascular Surgery, 58, 178.

Favaloro, R. G., Effler, D. B., Groves, L. K., Sheldon, W. C., Shirey, E. K., and Sones, F. M., Jr. (I970). Severe segmental obstruction of the left main coronary artery and its divisions: surgical treatment by the saphenous vein graft technique. Fournal of Thoracic and Cardiovascular Surgery, 60, 469.

Johnson, W. D., Flemma, R. J., Lepley, D., and Ellison, E. H. (1969). Extended treatment of severe coronary artery disease: a total surgical approach. Annals of Surgery, 170, 460.

Johnson, W. D., and Lepley, D., Jr. (1970). An aggressive surgical approach to coronary disease. fournal of Thoracic and Cardiovascular Surgery, 59, I28.

McCallister, B. D., Richmond, D. R., Saltups, A., Hallermann, F. J., Wallace, R. B., and Frye, R. L. (1970). Left ventricular hemodynamics before and I year after internal mammary artery implantation in patients with coronary artery disease and angina pectoris. Circulation, 42, 47I.

McCallister, B. D., Yipintsoi, T., Hallermann, F. J., Wallace, R. B., and Frye, R. L. (1968). Left ventricular performance during mild supine leg exercise in coronary artery disease. Circulation, 37, 922.

Murray, G., Porcheron, R., Hilario, J., and Roschlau, W. (1954). Anastomosis of a systemic artery to the coronary. Canadian Medical Association fournal, 71, 594.

Rees, G. M., Kremkau, E. L., Bristow, J. D., Green, G. S., Herr, R. H., and Starr, A. (I970). Left ventricular performance following vein bỳpass surgery for coronary artery disease (abstract). Circulation, 4I, Suppl. 3, 190.

Saltups, A., McCallister, B. D., Hallermann, F. J., Wallace, R. B., Smith, R. E., and Frye, R. L. (1971). Left ventricular hemodynamics in patients with coronary artery disease and in normal subjects: correlations with the extent of coronary artery lesions and the electrocardiogram. American fournal of Medicine, 50, 8.

Sarnoff, S. J. (1955). Myocardial contractility as described by ventricular function curves: observations on Starling's law of the heart. Physiological Reviews, 35, 107. 
Smith, H. C., Frye, R. L., Davis, G. D., Pluth, J. R., Sturm, R. E., and Wood, E. H. (I97I). Simultaneous indicator dilution curves at selected sites in the coronary circulation and determination of blood flow in coronary artery-saphenous vein grafts by roentgen videodensitometry. In Roentgen-, Cineand Videodensitometry: Fundamentals and Applications for Blood Flow and Heart Volume Determination, pp. 152-157. Ed. by P. H. Heintzen. Georg Thieme, Stuttgart.
Tatooles, C. J., and Randall, W. C. (I96I). Local ventricular bulging after acute coronary occlusion. American fournal of Physiology, 201, 45I.

Tennant, R., and Wiggers, C. J. (I935). The effect of coronary occlusion on myocardial contraction. American fournal of Physiology, 112, 35I.

Requests for reprints to Dr. B. D. Rutherford, Mayo Clinic, Rochester, Minnesota 5590r, U.S.A. 